\title{
24 DIVERSITY AND HUMAN FLOURISHING MADE VISIBLE IN THE SOUTH AFRICAN CONSTITUTIONAL COURT BUILDING
}

\section{Yolanda van der Vyver $^{1}$}

\section{INTRODUCTION}

The word "diversity" has become a key term in postmodern society and finds application in disciplines across the board. ${ }^{2}$ Since the advent of democracy in South Africa in 1994, the country has embraced the idea of societal diversity and cultural pluralism, which includes religion, language, ethnicity, race and political belief. The ideals of democratic South Africa seek to establish and maintain peaceful, free and healthy living conditions that promote human flourishing for its citizens and those who reside within its borders. Embracing diversity in South African society has proved challenging, due to past injustice and inequality, when viewing cultural representation and influence in the population. The 1993 Interim Constitution strived to address these challenges in the transition from the oppressive apartheid regime to a constitutional democracy, and the Constitution of the Republic of South Africa of 1996 strives to create a society based on democratic values, social justice and human rights.

The research question in this chapter is to explain how diversity and human flourishing and the aims of both the Interim Constitution and the Constitution are expressed in the Constitutional Court building in Johannesburg. We find that in the late twentieth century, legal scholars compared the law to cartographic, architectural and spatial images. This chapter starts with an explanation of these images in relation to the South African Constitution and the Constitutional Court and then places the building in its historical, geographical and typological contexts. The significance of its architectural symbolism can only find expression when considering these contexts. The historical context reveals the site as an urban palimpsest rich in historical information, the geographical context highlights the historical political tensions between the capital, Pretoria, and South Africa's commercial centre of Johannesburg, and the typological context reveals the evolution of architectural and legal spatial concepts since the nineteenth century.

1 The author holds a Master's degree in Architecture from the University of Pretoria and is a Doctoral candidate in the Department of Architecture at the University of the Free State, South Africa. She has been a practising architect since 1996, is a founding member of $\mathrm{Y}$ and $\mathrm{K}$ Architects, and a Fellow of the Association of Arbitrators.

2 Online at: https://www.jstor.org/stable/1343539?seq=1\#page_scan_tab_contents 


\section{RESEARCH METHODOLOGY}

The Constitutional Court was built on a provincial heritage site on Constitution Hill in Johannesburg. Since one of the aims of this chapter is to situate the Constitutional Court in its wider historical context and to determine the past of the historic space, it requires an historical research $\operatorname{method}^{3}$ and an interpretive-historical research strategy, ${ }^{4}$ which are both consistent with the nature of the research question. The system of inquiry or the paradigm in which the research is conducted is qualitative, because it depends on non-numerical verbal (written) evidence; "mythical", 5 along the lines of most scholarly work in history; and, when considering objectivity, naturalistic, ${ }^{6}$ since value-free objectivity is neither possible nor necessarily desirable.

The interdisciplinary nature of the research question means that the research employs strategies and tactics from other disciplines. Qualitative tactics were employed to gather and interpret evidence derived from archival and artifactual sources, from written texts and from observations made on a site visit on 18 April 2018. Architectural historian David Wang provides four interpretive lenses, as a part of research design, through which past phenomena can be viewed. In this chapter, one of these lenses, "absolute spirit", as postulated by philosopher G.W.F. Hegel, will be considered. Hegel believed that history was the movement of an absolute spirit and that communal consciousness, worldview or zeitgeist was the cause of historical change. His theory included the role of special individuals as agents who bring about change. In this chapter, special mention will be made of such individuals who acted in or against the spirit of their times in order to create change. Although the communal spirit tends to devalue individual lives, the progress of the communal spirit is dependent on the activity of individuals.

\section{A BRIDGE BETWEEN THE DIVIDED APARTHEID PAST AND A DEMOCRATIC FUTURE}

Peter Goodrich has written that the word "law" refers to a path, and that the law is a map, a compass or a route by which we find our way. ${ }^{8}$ Wessel le Roux has elaborated

3 Leedy PD. 1989. Practical Research: Planning and Design. New York: Macmillan, 125-137.

4 See Wang, in Groat L and Wang D. 2002. Architectural Research Methods. Hoboken NJ: Wiley, 135-171. Interpretive research is defined as "investigations into social-physical phenomena within complex contexts, with a view toward explaining those phenomena in narrative form and in a holistic fashion. Interpretive-historical research implies that the phenomenon is a past condition, relative to the researcher."

5 Robinson harks back to Ancient Greece when defining the two systems of inquiry as "science" and "myth". See Robinson JW. 1990. "Architectural research: Incorporating myth and science", Journal of Architectural Education 44(1):20-32.

6 Groat and Wang, Architectural Research Methods, 25-31.

7 Groat and Wang, Architectural Research Methods, 142-149. The four interpretive lenses are covering laws, absolute spirit, structuralism and post-structuralism.

8 Goodrich P. 1990. Languages of law: from logics of memory to nomadic masks. London: Weidenfeld and Nicholson, 213. Peter Goodrich is a professor of Law and Humanities at the Benjamin N. Cardozo School of Law in New York. 
on this cartographic imagery by commenting that the word and its metaphors are tied to spatial images related to the crossing and mapping of a territory. ${ }^{9}$ The 1993 Interim Constitution of South Africa described the law as a path on a "historical bridge" that makes the safe crossing of a treacherous chasm in the political landscape possible. The post-amble to the Interim Constitution stated that it "provides a historic bridge between the past of a deeply divided society characterised by strife, conflict, untold suffering and injustice, and a future founded on the recognition of human rights, democracy and peaceful coexistence and development opportunities for all South Africans, irrespective of color, race, class, belief or sex."10 The image of the bridge promised that transformation from apartheid to post-apartheid South Africa would follow a linear progression from one side of a conceptual dualism to another.

The concept of the "historical bridge" was applied in the landmark case of the state versus T. Makwanyane and M. Mchunu. ${ }^{11}$ The accused were found guilty of murder, attempted murder and robbery and received the death penalty during a trial in the Supreme Court that was concluded before the 1993 Interim Constitution came into force. The appeal to the Appellate Division of the Supreme Court against their convictions was dismissed. The court held that the accused should receive the heaviest sentence permissible according to law, but Section 277(1) of the Criminal Procedure Act No. 51 of 1977 that prescribed the death penalty as a competent sentence for murder, had become in conflict with Sections 9, 10 and 11(2) of the Interim Constitution of 1993, which had subsequently come into force. The appeal against their death sentences was postponed until the Constitutional Court could hear the constitutional issues. The Constitutional Court found that the death penalty was inconsistent with the provisions of the Constitution. In his decision, Judge Arthur Chaskalson referred to Etienne Mureinik's comment that, if the Constitution is to be a bridge away from a culture of authority, it should be clear what it must be a bridge to. "It must lead to a culture of justification ... If the Constitution is to be a bridge in this direction, it is plain that the Bill of Rights must be its chief strut."12

9 Le Roux W. 2004. “Bridges, clearings and labyrinths: the architectural framing of post-apartheid constitutionalism”, SA Public Law 19:629-665. Wessel le Roux is a professor in Public Law at the University of the Western Cape.

10 These words are taken from the first paragraph of the provision on National Unity and Reconciliation with which the Constitution concludes. Section 232(4) provides that, for the purposes of interpreting the Constitution, this provision shall be deemed to be part of the substance of the Constitution, and it shall not have a lesser status than any other provision of the Constitution.

11 S v Makwanyane and Another (CCT3/94) [1995] ZACC 3; 1995 (6) BCLR 665; 1995 (3) SA 391; [1996] 2 CHRLD 164; 1995 (2) SACR 1 (6 June 1995).

12 Mureinik E. 1994. "A Bridge to Where? Introducing the Interim Bill of Rights", South African Journal on Human Rights 10(1):31-48, 32. Etienne Mureinik (1954-1996) was a professor of Law at the University of the Witwatersrand. He helped draft the Bill of Rights for the new Constitution. 
Finally, the Constitution suggests a change in mental attitude from vengeance to an appreciation of the need for understanding, from retaliation to reparation and from victimisation to $u b u n t u$. It is a bridge between a history of gross violations of human rights and humanitarian principles and a future of reconstruction and reconciliation.

\section{HISTORICAL CONTEXT}

South Africa's first Constitutional Court was officially opened on 21 March 2004 on Constitution Hill in Johannesburg. The judges chose the site, where they had been housed in temporary accommodation since 1994. Their choice was not a neutral space. They chose the site of the Old Fort prison complex, consisting of four different buildings, namely the Old Fort (built by prison labour in 1893), the Number 4 prison for non-whites (built in 1902), the former women's prison (built in 1907) and the awaiting-trial block (built in 1928). Mahatma Gandhi, Nelson Mandela and other famous political figures were incarcerated in this complex before it was closed in 1983. It is an historic site and to quote former Constitutional Court judge, Justice Albie Sachs: "[T]his was a space of intense drama, of human emotion, of repression, of resistance. And here was the chance to convert negativity into positivity."13

These buildings originated under different authorities or historical states. The South African Republic or Boer ${ }^{14}$ Republic was known by its Dutch name, the ZuidAfrikaansche Republiek (ZAR). It was established in 1852 with the signing of the Sand River Convention. According to the Convention, the British Government would allow the Dutch emigrant farmers (Boers) in the geographical area north of the Vaal River to govern according to their own laws, with a policy of non-interference from both sides. However, the British annexed the ZAR in 1877, which led to the First Anglo-Boer War (Freedom War) of 1881. After the war, the ZAR was re-established, but the discovery of gold in 1886 led to the Second Anglo-Boer War, which was fought from 1899 to 1902. The ZAR was defeated and between 1902 and 1910 the area, now the Transvaal ${ }^{15}$ Colony, came under direct British rule. The Number 4 prison for non-whites and the former women's prison were built during this time. In 1910, the Transvaal Colony was incorporated into the Union of South Africa, and after Unification it became the Transvaal Province. This was when the awaiting-trial block was built. The Republic of South Africa only came into being in 1961.

The president of the ZAR, Paul Kruger, commissioned the Old Fort in 1892, on this strategic hill that today overlooks central Johannesburg. It was initially intended for white criminals produced by the growing gold mining town, but it became the

13 Online at: https://www.constitutionhill.org.za/pages/building-the-constitutional-court

14 Boer is the Dutch and Afrikaans noun for "farmer", referring to the descendants of Dutchspeaking settlers in South Africa and those who left the Cape Colony in 1838 with the Great Trek to settle in the Boer Republic.

"Transvaal" means the "area across the Vaal River". 
first military fort in Johannesburg in 1896 after the Jameson raid. ${ }^{16}$ The Boers built ramparts between 1896 and 1899, but they lost the fort in 1900 to the British during the Second Anglo-Boer War. After the war, the fort became a prison again, intended for white male prisoners, but this time under British control and with Boer soldiers imprisoned. ${ }^{17}$ The strife between Boer and Brit was subdued with the Union of South Africa in 1910 and when the National Party came into power in 1948, the system of apartheid institutionalised racism, which saw prisoners in the Old Fort segregated and non-white prisoners notoriously brutalised.

\section{THE SITE AS URBAN PALIMPSEST}

The archaeology of the site reveals different layers in the urban fabric and each layer represents a different political era in the history of South Africa. Each era has left behind visible remains as a reminder of the values and ideologies that these political cultures have shared and in order to understand the social and cultural meaning that has been embedded in the site, one has to understand the language that narrates the processes of their creation. The term "palimpsest"18 is usually associated with literary texts and is inherently tied to writing, but it has come to be used in other disciplines to denote something that was created for one purpose and later reused for another. In archaeology, it refers to layers of architectural remains; in landscape archaeology it refers to the way that different generations alter the landscape; and in literature, it refers to differing book editions and a multilayered record produced by layering text over time. It is used in literature and art to describe an object, place or idea that reflects history. The term can further be used with respect to discuss configurations of urban space and their unfolding in time. ${ }^{19}$

When the Constitutional Court was constructed in 2004 a new layer, representing a new political era, was added to the historic palimpsest of the site. This new layer was to be the physical embodiment of transformation in South Africa, embedded with new cultural and social meaning. Although created for the purpose of confinement, the site was reused and transformed into a space of freedom, ${ }^{20}$ dedicated to diversity

16 The Jameson Raid of 1895 was backed by Cecil John Rhodes, prime minister of the Cape Colony, whose ambition it was to fly the Union Jack from the Cape to Cairo. The unsuccessful raid was aimed at overthrowing president Paul Kruger's Republic.

17 Online at: https://www.constitutionhill.org.za/sites/site-old-fort

18 The word was derived from the Greek palimpsestos and the Latin word palimpsestus, which means "scratched or scraped again". Historically, a palimpsest is a page from a scroll, manuscript or a parchment roll from which the original text has been scratched off so that, for economic reasons, the page could be reused in another document.

19 Huyssen A. 2003. Present Pasts: Urban Palimpsests and the Politics of Memory. Stanford: Stanford University Press, 7.

20 Noble J. 2009. "Constitutional Court", in Joubert O (ed). 2009. 10 years + 100 buildings: Architecture in a Democratic South Africa. Cape Town: Bell Roberts Publishing, 116. Professor Noble was recently appointed as the head of the Department of Architecture at the University of the Free State. 
and human flourishing. Negativity was turned into positivity, as Justice Albie Sachs described it, and a new communal spirit was altering the urban landscape to reflect democratic values and ideologies. The building became the "historical bridge" that was to transform the trauma of its apartheid past into a spirit of reconciliation in its post-apartheid future.

Commemoration of traumatic memories, although not unique to South Africa, has been an important part of the post-apartheid healing process. ${ }^{21}$ Since the end of apartheid, various "sites of memory" have been established across South Africa to commemorate the struggle against apartheid and the trauma that it caused many South Africans. Together with literature, art and landscape, buildings constitute the most important externalisation of human memory. They are mnemonic devices that concretise remembrance by containing and projecting memories. They stimulate and inspire us to reminisce and imagine. "We cannot conceive or remember time as a mere physical dimension; we can only grasp time through its actualisations; the traces, places and events of temporal occurrence." ${ }^{22}$ Architectural structures facilitate human memory, but in a diverse society, especially one as politically loaded as South Africa, preserving the artefacts produced by past oppressors is a contentious issue. Whenever there is a significant socio-political change, the new leaders attempt to perform a memory reformulation ritual and erase the memories of their predecessors. ${ }^{23}$ That means that the demolition of existing structures that bore witness to trauma is always part of memory discourse and the question whether these structures should be maintained in order to remember, or whether they should be demolished in order to forget becomes part of the discourse. ${ }^{24}$

21 There was a global concern with trauma in the 1990s that found expression in a multinational holocaust discourse, the exploration of repression and the expression of a present repetitively haunted by the past. In South Africa, this discourse was energised by the Truth and Reconciliation Commission (TRC), which saw an intense interest in witness and survivor testimonies after apartheid. Memory practices in South Africa have a clear political function, but are affected and partly created by international coverage of memory obsessions (Huyssen, Present Pasts, 28). In post-apartheid South Africa, with its TRC, the issues of memory and forgetting are more than just concerns of the past. They have become part of the very political legitimacy of its regime today (Huyssen, Present Pasts, 94).

22 Pallasmaa J. 2009. “Space, place, memory and imagination”, in Treib M (ed). Spatial Recall: Memory in Architecture and Landscape. New York: Routledge, 189-190.

23 Elleh N. 2002. Architecture and Power in Africa. Westport: Praeger, 163.

24 The destruction of Nazi architecture aimed at glorifying Hitler, such as his Chancellery in Berlin, versus the maintenance of Nazi structures to commemorate trauma, such as the concentration camp at Auschwitz, are good examples of this discourse between historic trauma and collective memory. Hitler's Chancellery in Voßstraße in Berlin was his palatial headquarters designed by Albert Speer to intimidate foreigners and impress Germans. After the German defeat, the Russians finally demolished the remains of the building and used it to quarry stone for their war memorials in Berlin. See Sudjic D. 2005. The Edifice Complex: How the Rich and Powerful Shape the World. London: Penguin Books, 45. 
Trauma is located on the threshold between remembering and forgetting, seeing and not seeing, transparency and occlusion, and experience and its absence. ${ }^{25}$ The desire to commemorate trauma, thus, goes hand-in-hand with the desire to suppress memories.

On Constitution Hill, the same question came into play. To what extent would the existing structures be retained? The development on Constitution Hill required some demolition, but it was done with careful consideration, without erasing the memory of its traumatic past completely. The new Constitutional Court was built just downhill from the Old Fort, separated from the fort itself by one of its ramparts, amidst the abandoned structures of the awaiting-trial block and the Number 4 prison, which were turned into a museum. Once threatened with demolition itself, the Old Fort was declared a national monument in 1964. The awaiting-trial wing of the former prison was demolished but the stairwells were kept and incorporated into the new building with light boxes on top, as a reminder of how South Africa has overcome the dark days of oppression. Bricks from the demolished awaitingtrial wing were used to construct the new court building. ${ }^{26}$

In 1845, English essayist Thomas de Quincey wrote an essay titled "The Palimpsest" where he stated that "even though the process of layering which creates a palimpsest was born out of a need to erase and destroy previous texts, the re-emergence of those destroyed texts renders a structure that privileges heterogeneity and diversity" ${ }^{27}$ Cities are palimpsests of history, incarnations of time in stone and sites of memory extending both in time and space, ${ }^{28}$ and Constitution Hill is a palimpsest very rich in different layers of history which become visible while deciphering the palimpsest.

\section{GEOGRAPHICAL CONTEXT}

With the Union of South Africa, the former capital of each of the South African colonies became a different executive capital. ${ }^{29}$ Although Johannesburg is not one of South Africa's three capitals, it is the largest city in South Africa, the economic capital of the country and the seat of the Constitutional Court. Johannesburg is known for societal diversity, and cultural and political pluralism have become characteristic of its form. Diversity is more pronounced in any urban setting, as opposed to the rural areas where monoculture is more probable. With an increase in global (im)migration, diversity in the urban landscape has become a universal

25 Huyssen, Present Pasts, 101.

26 See Jethro D. 2019. "Liberated waste: heritage and materiality at Robben Island and Constitution Hill, South Africa", International Journal of Heritage Studies (June):259-276.

Online at: https://lucian.uchicago.edu/blogs/mediatheory/keywords/palimpsest/

29 Pretoria, the capital of the Transvaal Colony, became the seat of the administrative branch of government. Cape Town, the capital of the Cape Colony, became the home of the South African parliament and thus the legislative capital. Bloemfontein, the capital of the Orange River Colony, became the judicial capital and host to the Appellate Division. 
phenomenon. The historical political tensions between the capital, Pretoria, and South Africa's commercial centre, Johannesburg, can best be illustrated by the example of the Rivonia trial.

\section{Mandela, the Old Fort and the Palace of Justice}

The Old Fort in Johannesburg and the Palace of Justice in Pretoria have more in common than just the architect who designed the buildings through the ZAR's Public Works programme (see Typological Context below). Nelson Mandela was imprisoned in the Old Fort twice, first in 1956 and then again in 1962. Both times, despite being held in Johannesburg, he was tried in Pretoria. The first trial, the Treason Trial, was held in the Old Synagogue near Church Square between March 1956 and August 1961. The second trial, the Rivonia Trial that ended in his 27 years' imprisonment, was held in the Palace of Justice on Church Square. The Old Fort housed white male prisoners, but Mandela was held there because his captors feared his influence on other black prisoners. Karin van Marle argues that the state's decision to move these trials from Johannesburg to Pretoria was the ultimate political statement. ${ }^{30}$

Joel Joffe wrote that Pretoria was a civil servant's town with a strong pro-government, pro-Verwoerd sentiment where Afrikaner nationalism was rife. Pretoria residents would not be supporters of the accused, nor would they stage anti-government demonstrations outside the Court as was expected from Johannesburg residents. Transferring the prisoners to Pretoria every day was demoralising to the accused and an inconvenience to all, since the prosecutor and all the security police involved in the Rivonia raid were stationed in Johannesburg. ${ }^{31}$ Karin van Marle further remarks that none of the Pretoria journals of the 1960s that focused on the architecture, buildings and public spaces of Pretoria, mentioned that the Rivonia Trial was taking place in the Palace of Justice, as if the narrative surrounding Mandela in Pretoria had to be controlled.

\section{TYPOLOGICAL CONTEXT}

\section{The ZAR's Old Fort and the Palace of Justice}

Dutch-born architect Sytze Wopkes Wierda designed the Old Fort. It is important to mention Wierda's name, because he also designed the two most prominent buildings of the ZAR: the Old Government building, or Raadzaal, as it was

30 Van Marle K. 2015. “Mandela in/and Pretoria”. Image \& Text: A Journal for Design (25):142-160. Karin van Marle is currently a professor in the Department of Public Law at the University of the Free State, where she teaches Legal Philosophy and Legal Interpretation.

31 Joffe J. 2009. The State versus Nelson Mandela: The Trial that Changed South Africa. London: Oneworld Publications. Joel Joffe (later Lord) (1932-2017), South African-born human rights lawyer and peer, now retired from the British House of Lords, and the instructing attorney on the defence team during the Rivonia trial. 
popularly known, and the Palace of Justice, the Republic's first court building. These buildings were built on Church Square in Pretoria, 56 kilometers north of the Old Fort in Johannesburg, in 1891 and 1899 respectively. This chapter aims to place the Constitutional Court in its geographical context, in order to highlight the historical political tensions between the capital, Pretoria, and South Africa's commercial centre, Johannesburg, and it aims to place the building in its typological context, in order to illustrate how architecture and legal spatial concepts have evolved from the late nineteenth-century ZAR to the early twenty-first century post-apartheid South Africa. The Palace of Justice building by Wierda plays an important role in achieving both aims, firstly as the geographic counterpart to the Old Fort complex on Constitution Hill and secondly as the typological counterpart to the new Constitutional Court building.

After gold was discovered in the Transvaal, the economic power of the ZAR increased and the influx of capital changed the face of its architecture. This prosperity led the government to search for an own architectural identity that would emanate dignity and prestige. President Paul Kruger did not deem the local draftsmen competent enough for such an important task and looked towards bringing in knowledgeable, sophisticated, Calvinist, Dutch architects to design government buildings for the newly rich Republic. This would also strengthen the Dutch/Afrikaans language and the presence of the Dutch Reformed Church. ${ }^{32}$ The ZAR had express constitutional requirements that those in civil service belong to the Dutch Reformed Church, so the Dutch immigrants that came to do service were Calvinist and probably drawn by these specific cultural and religious circumstances. There was also an actual religious dimension to their design skills and their designs, because in nineteenth century Netherlands, training of professional architects and engineers occurred along the religious divides of Protestantism and Catholicism.

When the Volksraad ${ }^{33}$ decided to appoint a state architect in 1887, Wierda and his apprentice Klaas van Rijsse were still working in the Netherlands. Because they were both members of the Dutch Reformed Church, they could apply for their respective positions in the civil service of the ZAR: Wierda as state architect and van Rijsse as his chief assistant. ${ }^{34}$ Together they built up the Department of Public Works through which the desire for identity and independence from the British was expressed. ${ }^{35}$ We find a communal consciousness, worldview or zeitgeist that was the cause of historical change, expressed in the architecture of the time. The government could now flourish and commission the construction of grand designs that symbolised the Afrikaners' struggle with Britain since 1795, a struggle

32 Holm A and Viljoen D. 1993. Mure wat praat: die verhaal van die Ou Raadsaal en sy mense [Walls that speak: the story of the Old Council Chamber and its people]. Johannesburg: Chris van Rensburg Publikasie (Pty) Ltd., 15.

"Volksraad" means "people's council" and refers to the parliament of the ZAR. (eds). Eclectic ZA Wilhelmiens: A Shared Dutch Built Heritage in South Africa. Pretoria: Visual Books, 15-17. 
which culminated in the Afrikaners' long-awaited victory, freedom and independence from Britain. Ironically, it was economic change that led to the two Anglo-Boer Wars and the end of the Republic.

Both the Old Fort and the Palace of Justice were symbols of power, but the designs were executed differently. Wierda was influenced by the late nineteenth century Dutch architectural trends, which included applying diverse historical styles to the diverse building typologies that were emerging at that time, so that each style could lend the right character to each typology. The Old Fort consisted of a group of long rectangular single and double story buildings with thick walls, gable ends and corrugated roofs. Architect KEF Gardiner described the exterior as uninteresting and similar to any stronghold, and he added that the rectangle of ramparts surrounding the concentration of buildings has essentially camouflaged the Old Fort. He noted that the ramparts contained and concealed offices, storerooms and gun emplacements and marveled at the enormous strength of the ceilings that could sustain the tremendous weight of the earthworks above. He described the vaulted tunnels through the ramparts that gave access to the buildings, as well as tunnels to the gun positions, which enhanced the claustrophobic sense of enclosure. ${ }^{36}$ As punitive and fortified structures, they emanated the power of the state. ${ }^{37}$

The Palace of Justice, on the other hand, was designed to resemble a palace. Late nineteenth-century Dutch architectural trends deemed the Renaissance style appropriate for government buildings, because it exuded dignity and authority. Architectural author and conservationist Désirée Picton-Seymour claimed that the Palace of Justice was built in the Italian Renaissance or palazzo style ${ }^{38}$ and although influenced by contemporary Flemish and French Renaissance revival designs, Wierda's building was in a uniquely South African Republican style, ${ }^{39}$ a more somber style, as opposed to the frivolity of the Victorian architecture of the British.

36 Gardiner KEF. 1969. "A visit to the Old Fort, Johannesburg", Lantern December:84-88. Gardiner was an author and architect, active in Johannesburg from the late 1920s to the late 1950s. Online at: https://www.artefacts.co.za/main/Buildings/archframes. php?archid $=563 \&$ countadd $=1$

37 Author's own comment.

38 Picton-Seymour D. 1977. Victorian Buildings in South Africa: Including Edwardian and Transvaal Republican Styles, 1850-1910. Cape Town: Balkema, 6.

39 The contribution that Dutch-born architects have made to the architecture of the ZuidAfrikaansche Republiek (ZAR) (1854-1902) through its Public Works Department (Departement Publieke Werken) (1887-1901) has been given three different names by different authors. Picton-Seymour (1977) called it the "Transvaal Republican Style" and made a clear distinction between this style and Victorian Architecture, which was more orientated towards the Neo-Gothic and Neo-Renaissance; Holm and Viljoen (1993) calls it the "ZAR-style". More recently, the term "ZA Wilhelmiens" has been coined by a group of architect researchers, affiliated with the University of Pretoria, to express the Dutch link of the period that roughly coincides with the life of the Dutch queen, Wilhelmina (1880-1962). See Clarke NJ and Kuipers M (eds). 2015. Re-centring Tshwane: Urban Heritage Strategies for a Resilient Capital. Pretoria: Visual Books, 2. 


\section{A NEW COURT TYPOLOGY}

The design of the Constitutional Court was the result of an international competition. The collective view of the Judiciary of the New South Africa was expressed in the competition brief and the winning design took the ideals in the brief as absolute architectural value. ${ }^{40}$ Even though the judges chose a site of historical trauma, one that is an urban palimpsest containing the architectural remains of previous oppressive regimes, the new layer that was to be added to this palimpsest had to stand in stark contrast to its historical and typological precedents. The following section aims to explain how these post-apartheid ideals were made visible in the Constitutional Court building.

The first aspect deals with diversity. The building's Award of Merit citation called it a robust hybrid, just as South Africa is a hybrid. ${ }^{41}$ Firstly, diversity is expressed in the use of building materials. A diverse range of modern building materials are combined with the recycled bricks from the demolished awaiting-trial wing that were used to create the rough wall surface of the court chamber. Secondly, it is expressed through language. South Africa has eleven official languages, which reflect the cultural diversity of the nation. All eleven languages are acknowledged by providing the name "Constitutional Court" in differently coloured letters in each official language on the entrance façade. Thirdly, diversity is expressed in the choice of location, since Johannesburg has historically been a more diverse city than Pretoria. The vibrancy and variety of Johannesburg street life is celebrated by inviting it into the building through windows in the external walls. But finally, diversity is best expressed in the curated art collection on display on the court walls, judges' chambers and meeting rooms. The collection started with Justices Albie Sachs and Yvonne Mokgoro's drive to decorate the court in a way "that would befit the dignity of each person that enters the court seeking justice", for which they commissioned a tapestry, titled Humanity by Joseph Ndlovu. From there the collection grew to include many donations by prominent South African artists, depicting their interpretation of democracy, traumatic memories of past injustices and the Bill of Rights. Investment from the private sector was prohibited to avoid a conflict of interest with possible future litigants, but grants from European governments and North American philanthropic organisations were accepted. ${ }^{42}$

The Constitution's democratic ideals were translated directly into the architectural language of the building. This resulted in a light, transparent and open design. The main foyer is accessed through enormous timber double doors, from which the 27 provisions in the Bill of Rights, what legal scholar Etienne Mureinik called the struts of the historical bridge, were carved. To the bridge metaphor, a truly African one was added, namely the practice of justice under a tree, an age-old African tradition of settling disputes under the protection of an important tree. The foyer is a literal

40 Online at: https://www.artefacts.co.za/main/Buildings/bldgframes.php?bldgid=7712

41 The Design Workshop SA received the South African Institute of Architects (SAIA) Award of Merit and Award for Excellence in 2008.

42

Online at: https://www.constitutionhill.org.za/pages/constitutional-court-art-collection 
translation of this African concept. Instead of being an intimidating space, the foyer is open with high ceilings, supported by slanted columns that remind of the indigenous trees of South Africa. The same image is embodied in the emblem of the South African Constitutional Court: a tree with branches that spread over the people it protects. Jonathan Noble, a South African professor of architecture, describes the dappled light that filters though the tree-like structures into the colourful interior of the welcoming reception, and he places it in stark contrast with authoritarian structures of the past. ${ }^{43}$

The law as a path has been made visible in the approach to the building. According to Noble, the footprint of the building is informed by uban clarity which elegantly combines its institutional function with a transparent public interface. The approach is through two pedestrian axes: an east-west axis and the terraced stairs adjacent to the building, aptly named the African steps, that form the secondary axis connecting north to south. "The court chamber is accessible directly off Constitution Square as an inviting gesture to repudiate official procession and monumentality." Inside the court chamber, a row of horizontal windows has been set up behind the seats of the judges. While the windows are at the head-height of judges on the inside, they are on ground level on the outside. Those sitting in the court have a view of the feet of passersby moving along, above the heads of the judges, to remind that in a constitutional democracy the role of the judges is to act in the interest of the people. The gallery is filled with public art and connects the foyer to the library and the judges' quarters. The public circulates parallel to the secluded chamber of the judges. There is thus a clear definition between private and public functions, but it is done subtly. There are slanted openings in the dividing wall that establishes a dialogue between the public and private areas.

Another professor of South African architecture, Pattabi Raman, explains that the typology of somber and forbidding legal environments have been inverted and monumentality was carefully avoided by allowing the building to meet the ground rather than placing it on an imposing podium. Raman adds that the transparency and lightness, as well as accessibility, with the internal arcade adds to the concept of reflection before making judgment. All these factors contribute to the conversion of a former place of confinement into one of liberation. Raman believes that South African designed buildings after apartheid responded well to the evolution of civil society. ${ }^{4}$

\section{THE PALACE OF JUSTICE AND JUDICIARY INDEPENDENCE}

The involvement of the constitutional judiciary in the choice of site, design brief, architectural execution and art collection is a unique contribution to South African legal space. The importance of judicial independence in South Africa justifies a brief

43 Noble, "Constitutional Court", 116.

44 Raman P. 2009. "Change and continuity in Contemporary South African Architecture and Urbanis", in Joubert (ed), 10 years +100 buildings, 15 . 
exploration of its evolution since the nineteenth century. We therefore return to the historic Palace of Justice and the ZAR of Paul Kruger.

The struggle between the state (president Paul Kruger), the judiciary (chief justice John Kotzé) and the architect (Sytze Wierda) during the planning phases of the Palace of Justice stands in stark contrast to the conception of the Constitutional Court. ${ }^{45}$ Firstly, Kotzé and the Bar ${ }^{46}$ objected to the Volksraad's 1892 decision to house the Supreme Court in the newly completed Raadzaal building on Church Square, because uniting the government and judiciary under one roof, would have negatively impacted on the perception of the Court's independence and would have increased the possibility of ultimate centralised power under the President. The objection was upheld, and a year later Kruger instructed Wierda to draw up plans for a new Supreme Court building. Secondly, Kotzé and the judges unanimously rejected Wierda's first design and suggested the creation of a building commission to assist Wierda, but in essence it secured the legal community's hold over the design process. The commission claimed that the style and façade did not do justice to the status and prestige of the Supreme Court and suggested a design in the old Dutch Renaissance style because "Roman Dutch Law required Dutch doctrinal and aesthetic traditions as reference points". ${ }^{47}$

An upset Wierda insisted that the Dutch Renaissance style was too expensive for the ZAR and recommended the Italian Renaissance style, which was cheaper and could sufficiently express the status and dignity of the Supreme Court. The Palace of Justice was also to contain offices for other state departments, a decision to which Kotzé further objected, once again insisting on the importance of housing the judiciary in a separate building to maintain independence. Karel Bakker explained Wierda's resistance to Kotzé's insistence on Dutch architecture with stepped gables: "Wierda's newly-formed ZAR-style, a free mix of Neo-Classical and other European architectural elements, reflected the sober Protestant Republican values that would be suitably impressive and have the stature of a house of Parliament." 48 According to Le Roux, the ZAR-style of the Palace of Justice is "an expression of self-contained and eternal authority, captured by aspirations to perfect symmetry in which all the different elements of the design are dominated by an overall harmony". The President and the Chief Justice thus both attempted to exploit the design and construction of the Palace of Justice in order to strengthen their own positions in the ZAR, while the architect struggled to protect the integrity of his own architectural design.

45 Le Roux W. 2003. "Studying legal history through courtroom architecture: scattered comments on the Palace of Justice, Church Square, Pretoria", Codiccillus 44(1):55-63.

The "Bar" refers to the legal profession as a whole. 
Putting style issues aside, Le Roux maintains that it was the status, power and independence of the Supreme Court and its judges that was at the centre of this struggle. Kotzé set out on a law reform programme after his arrival in 1877, and with the discovery of gold in 1886 and subsequent industrialisation, he saw increased political oppression of the uitlanders. ${ }^{49}$ His aim was to extend and intensify his reform programme to include the protection of the rights of minorities with no political representation in court. He further wanted the Supreme Court to have powers of constitutional review over the actions of the Volksraad and over president Paul Kruger. ${ }^{50}$ This met with fierce resistance and the Volksraad retaliated with adopted legislation requiring Kotzé and other judges to renounce their power of review and accept the Volksraad as the highest authority in the Republic. When Kotzé insisted on exercising his power of review, president Paul Kruger immediately dismissed him as Chief Justice. After his dismissal, Kruger instructed that a third floor be added to the partly completed building to alleviate the shortage of offices for the ZAR civil service. Kotzé's dream to have a building in an appropriate style exclusively devoted to the administration of justice was shattered. Holm and Viljoen find that the addition of a third floor disrupted the balance of the façade, resulting in what appears to be an eclectic mix of elements without any integrating context. ${ }^{51}$

When the Anglo-Boer War broke out, the building was still devoid of internal ornaments and fittings and all work had to stop. The Palace stood empty until June 1900, when the British forces took over Pretoria. ${ }^{52}$ During the war, the Palace of Justice was turned into a hospital for British soldiers, known as the "Irish Hospital". ${ }^{53}$ The advocates' robing room was used as a mortuary. After the war, in 1902, it became the home of the Supreme Court of the Transvaal.

Le Roux comments that Kotzé's confrontations with the architect Wierda about the design of the Palace of Justice is paralleled only by the time and energy that the Constitutional Court judges, especially Justice Albie Sachs, invested in choosing the site and the design for the construction of the new Constitutional Court building. It was important to dramatise physically the symbolic significance for the postapartheid project of law transformation and the move in South African jurisprudence away from a culture of authority to a culture of democratic dialogue and persuasion.

49 An uitlander was a British immigrant living in the ZAR who was denied citizenship by the Boers for cultural and economic reasons. Online at: https://en.oxforddictionaries. com/ definition/uitlander

50 Kotzé held that the Supreme Court had the constitutional power to test both the form and content of Volksraad decisions and to declare those decisions invalid. Le Roux, "Studying legal history through courtroom architecture", 58.

51 Holm and Viljoen, Mure wat praat, 12.

52 Ackerman M. 2002. "Palace of Justice - A case of beauty restored", Jaarboek (Africana Vereniging van Pretoria) [Yearbook (Africana Association of Pretoria)] 46(19):108-112.

53 Rex HM. 1956. Die geskiedenis van die eerste ou goerwermentsgebou en sy voorlopers in Pretoria [The history of the first old goverment building and its predecessors in Pretoria]. MA Thesis, University of Pretoria, 100. 


\section{CONCLUSION}

In order to place the building in its historical context, the Dutch architectural trends of the late nineteenth century were considered in the study of this chapter. Diverse building typologies were emerging at that time, and diverse historical styles were applied to each typology so that each style could lend the right character to each typology. First, fort typology was compared to court typology. The Old Fort and the Palace of Justice were designed by the same architect as part of the same Public Works programme, but they differed considerably in terms of style. In order to illustrate how architecture and legal spatial concepts have evolved from the late nineteenth-century ZAR to the early twenty-first century post-apartheid South Africa, the Palace of Justice, as an example of traditional judicial architecture, was placed in opposition to the Constitutional Court building.

The Constitutional Court in Johannesburg and its architectural and legal spatial concepts have evolved from traditional court typology that had the intention to intimidate and impress, to a concept with the intention to contribute to peace building, conflict resolution and the development of human flourishing under the law. Where the Palace of Justice asserted its authority through monumental architectural expression in an urban spatial context, the Constitutional Court represents a judiciary that has become a symbol of reconciliation, one that enters into memory discourse in an attempt to deal with historical trauma. Where the Palace of Justice did not represent societal diversity and cultural pluralism (the ZAR had a dominant homogeneous, white, Afrikaans, Protestant culture as well as a strict policy of citizenship), ${ }^{54}$ the architecture of the Constitutional Court building endeavours to express the diversity of a multi-cultured, post-apartheid South Africa and its aim is the promotion of equality and human flourishing under the new Constitution in a climate of reconciliation. Its architecture reflects post-apartheid legal order, which means diversity, dialogue and persuasion.

The spatial images have progressed from the law as a path or a map, the South African constitution as an historical bridge and justice as a clearing under a tree. Le Roux linked these spatial images to the architecture of the Constitutional Court building, which was the physical dramatisation of legal transformation in South Africa. "The design reflects a deliberate attempt to introduce a new aesthetic into South African law, which centers on the architectural depiction of law as a clearing under a tree, from walking over a bridge to stepping into a clearing."

54 Kruger saw the need for a second Volksraad, which he created in 1890 to alleviate the political pressure placed on him by the uitlanders. Before 1890, immigrants could naturalise and vote after residing in the ZAR for five years. After the discovery of gold, uitlanders streamed into the Republic and Kruger feared that these new citizens would elect a regime sympathetic to the British. New voting rights determined that uitlanders could vote for the second, subservient Volksraad after four years, but could only vote for the first Volksraad after ten years. All the second Volksraad's decisions had to be ratified by the first Volksraad (Holm and Viljoen, Mure wat praat, 26). People of colour were in any case excluded. 
The Palace of Justice as an example of traditional court architectural typology witnessed the strife between the state and the judiciary at the end of the nineteenth century, between Boer and Brit at the beginning of the twentieth century and between the Afrikaner national state and Mandela and other accused in the 1950s and 1960s. Wessel le Roux believes the building still tells an important story about the conflicts and politics built into the foundations of South African law.

The administration of justice in the South African Republic during the last decades of the nineteenth century has been celebrated as a victory for the intellectual dignity and worth of Roman Dutch law in the face of British imperialism. It is not surprising that this historiography presents the Palace of Justice as a monument to the value of the Roman Dutch legal heritage of the early republican Afrikaners, a monument defying the military defeat of the Boer Republics at the hands of the British.

Human rights activism and the creation of artworks are presented by comparative literature scholar Andreas Huysen as the solution to dealing with trauma. He explains that:

The transnational discourse of human rights may give us a better handle than the transfer of psychoanalysis into the world of politics and history. It is the function of public memory discourses to allow individuals to break out of traumatic repetitions. Human rights activism, truth commissions and juridical proceedings are better methods for dealing with historical trauma. Another way is the creation of objects, artworks, memorials, public spaces and commemoration of historical trauma and national memory practices..$^{55}$

In this regard, the design of the Constitutional Court building and the art works that it contains successfully commemorate historical trauma.

The past and the present are always in a dialogue on the historic site that is Constitution Hill. The site balances a temporal dichotomy. On the one hand there is the physical context, which includes the current built environment (the present) and on the other hand there is the historical context (the past). The result is a tension between the new democratic legal and political culture and the old authoritarian public buildings in which this culture is supposed to flourish. The archaeology of the site reveals layers of time wherein structures were created, changed, demolished and recreated. It reveals itself as a palimpsest rich in historical information. 